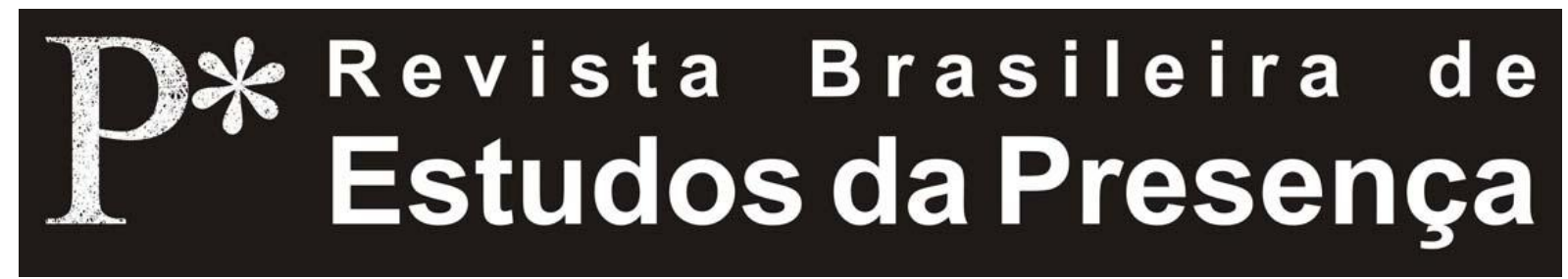

DOI - http://dx.doi.org/10.1590/2237-266022415

ISSN 2237-2660

\title{
A Presença Performativa nas Artes da Cena e a Improvisação
}

\author{
Gisela Reis Biancalana \\ Universidade Federal de Santa Maria - UFSM
}

\begin{abstract}
RESUMO - A Presença Performativa nas Artes da Cena e a Improvisação - Este artigo faz uma reflexão sobre a relevância do aspecto improvisacional oriundo das artes performativas como elemento fomentador da presença cênica. Performances podem ser definidas pelo momento em que um ou mais corpos mostram-se para outros e a presença é aqui entendida como a habilidade do performer para atrair a atenção do espectador para si. $\mathrm{O}$ aspecto improvisacional inerente a estas situações pode ser aplicado em vários níveis e de várias formas, mas depende essencialmente do performer em seu desejo de fazer, ou seja, ao entregar-se psicofisicamente a sua arte.

Palavras-chave: Performance. Presença. Artes Cênicas. Improvisação. Desejo.
\end{abstract}

\begin{abstract}
The Performative Presence in the Scenics Arts and the Improvisation - This article makes a reflection about the relevance of improvisation aspect in the performative arts as a fomenter element of scenic presence. Performances can be defined by the moment when one or more bodies shows themselves to other people eyes and the presence here means the performer ability to attract the viewer's attention to himself. The improvisational aspect comes out of these situations can be applied at many levels and many ways but mainly depends on the performer in his desire to do, namely, in giving psychophysically himself to his art.
\end{abstract}

Keywords: Performance. Presence. Scenic Arts. Improvisation. Desire.

\section{RÉSUMÉ - La Présence Performatif dans l'Art de la Scene et}

Gisela Reis Biancalana, A Presença Performativa nas Artes da Cena e a Improvisação

R.bras.est.pres., Porto Alegre, v.1, n.1, p. 121-148, jan./jun., 2011.

Disponível em http://www.seer.ufrgs.br/presenca 
l'Improvisation - Cet article se penche sur la pertinence de l'aspect d'improvisation des arts du spectacle en provenance de développeurs dans le cadre de présence scénique. Les performances peuvent être définis lors de l'un ou plusieurs organismes présentent pour les autres et la présence ici signifie la capacité de l'interprète pour attirer l'attention du spectateur à lui-même. L'aspect d'improvisation inhérente à ces situations peut être appliquée à différents niveaux et de différentes manières, mais dépend surtout de l'interprète dans son désir de faire, à savoir, en se donnant à son art psychofisicment.

Mots-clés: Performance. Présence. Arts de la Scène. Improvisation. Désir.

As atividades performativas são manifestações que, historicamente, marcam presença nos diversos contextos socioculturais em que se inserem. Os eventos artísticos, sejam os que tendem a ser mais formalizados, sejam os mais transgressores; as situações festivas ou religiosas, sejam sagradas ou profanas; enfim, é indiscutível a força impactante das atividades performativas. Os performers, por sua vez, procuram desenvolver elementos indispensáveis para realizar seu ofício. Entre os elementos mais buscados pelos performers está a habilidade de atingir um estado corporal psicofísico capaz de atrair a atenção do público. Este estado tem sido chamado de presença cênica e vem sendo bastante discutido nos meios teatrais.

Desta forma, tornou-se necessário definir, antes de tudo, o entendimento de performance e de presença cênica abordados, para que possam, posteriormente, ser vislumbrados a partir de seu aspecto improvisacional, como se propõe a presente reflexão. A performance caracteriza o momento em que se manifestam um ou mais corpos para apreciação de outros com as mais diversas formas e funções. Nas artes da cena o fenômeno performativo não pode existir se não há alguém fazendo algo para alguém, tal como postula Schechner (2003) em seus Estudos da Performance. A presença cênica é entendida como a habilidade do performer de estabelecer uma relação de troca com o público ao atrair sua atenção para a performance.

Gisela Reis Biancalana, A Presença Performativa nas Artes da Cena e a Improvisação

R.bras.est.pres., Porto Alegre, v.1, n.1, p. 121-148, jan./jun., 2011.

Disponível em http://www.seer.ufrgs.br/presenca 
$\mathrm{Na}$ tentativa de engendrar um entendimento sobre a beleza poética das manifestações artísticas que dependem da presença destes corpos em performance como matériaprima de seu fazer, procurou-se iniciar esta reflexão explorando, brevemente, pressupostos conceituais sobre as artes, em especial as artes da cena, e trespassá-las pelo complexo mundo contemporâneo. Subsequentemente, buscou-se abordar os processos improvisacionais no contexto das artes cênicas para situar a presença dos corpos em performance que a sustentam enquanto foco da reflexão proposta.

A cultura integra as artes em seu amplo leque de expressões e as artes da cena multiplicam-se entre as inúmeras formas de manifestações artísticas. Assim sendo, explorar os conceitos de cultura é também fundamental para entender a arte como produção de conhecimento. Atualmente, o próprio termo cultura é cultural, pois surge historicamente "[...] de um diálogo da sociedade consigo mesma [...] para responder a diversas questões sobre a natureza da vida social" (Schelling, 1990, p. 21). O termo Cultura é abrangente, e carrega consigo séculos de história, brevemente percorrida aqui, apenas no intuito de situar o espaço das artes e das artes cênicas. A abordagem antropológica contemporânea considera a cultura como resultante das relações sociais que determinados grupos, sejam eles delimitados por etnia, religião ou nação, mantêm entre si e com outros grupos, porém, considerando os “[...] caracteres distintivos que apresentam os comportamentos individuais, dos membros deste grupo, bem como suas produções originais (artesanais, artísticas, religiosas...)" (Laplantini, 1996, p. 120). A amplitude referida remete-se a esta imensa variação de desdobramentos abarcados. Observa-se, assim, que o termo cultura é bastante complexo por inserir-se em um abrangente espectro de produções sendo registradas a séculos pela história das civilizações. Assim, a cultura é composta por sistemas de significados, de atitudes e de valores compartilhados através de elaboradas formas simbólicas. Entre as diversas formas de manifestação cultural do ser humano estão as artes. As artes são muito mais antigas que o 
surgimento do termo cultura, mas está incorporada no seu amplo universo de manifestações.

Desta forma, os registros das diversas expressões artísticas estudadas ao longo da história apontam para a existência do desejo de fazer, presente em alguns seres humanos. Muitos são os filósofos, historiadores, antropólogos e sociólogos que se preocupam em discorrer sobre qual o sentido, como se transformaram no tempo e no espaço, como se organizam e como se manifestam essas motivações humanas. O desejo de fazer arte, visto como motivação humana, pode ser uma pista para as discussões sobre diversas polêmicas que circundam as experiências artísticas, entre elas a existência do dom ou talento natural, compreendido, algumas vezes, como um dos detonadores da presença cênica.

Segundo Chauí (1995), a religião e o trabalho foram as duas primeiras formas de manifestação cultural do ser humano na história. Consequentemente, foram também as responsáveis por instituir as primeiras formas de organização social, que se estabeleciam através de rituais simbólicos, entre as quais estão as artes. Desta forma, a arte surgiu inseparável de ambas. É válido notar que sua origem religiosa contribuiu significativamente para que a obra de arte tivesse uma qualidade aurática que perdura, em algumas perspectivas, até os dias atuais, desdobrando-se nas discussões sobre a crença no dom artístico. Desse modo, a obra de arte em sua qualidade aurática é algo que transfigura e distancia a realidade próxima colocando-a como transcendental. Ao considerar a origem da arte ancorada na perspectiva do trabalho, contribui para sua compreensão enquanto prática e produção de conhecimento. Nas artes, a produção do conhecimento ampara-se na subjetividade, trampolim para a objetividade de suas bases técnico-expressivas. Nas artes da cena, a transcendência dos elementos meramente objetivos se sublima pelos performers que emanam sua presença cênica.

A presença cênica, neste universo de opiniões díspares, vaga apoiada em dois sentidos opostos. Um deles acredita que a presença está relacionada ao dom divino ou talento natural. $\mathrm{O}$ outro acredita na 
possibilidade de desenvolvê-la pelo árduo trabalho técnico-expressivo em laboratório, via processos formativos especializados. Entre estes dois sentidos reside uma infinidade de discussões menos polarizadas formando um arsenal de posicionamentos inconclusivos. A crença na qualidade aurática da arte e no dom ou talento natural do artista reflete-se diretamente no desenvolvimento dos processos formativos e criativos. Quanto mais se acredita no dom, menos se investe na formação e, quanto mais não se acredita no dom, maior o investimento nos processos educativos com a ocupação dos espaços de ensino formais e informais por parte dos artistas. De acordo com Chaú (1995, p. 320), o conceito de aura foi investigado pelo filósofo alemão Walter Benjamin enquanto,

[...] a absoluta singularidade de um ser - natural ou artístico -, sua condição de exemplar único que se oferece num aqui e agora irrepetível, sua qualidade de eternidade e fugacidade simultâneas, seu pertencimento necessário ao contexto onde se encontra e sua participação numa tradição que lhe dá sentido.

A origem das reflexões sobre a presença cênica pode ter, então, seus primórdios nas primeiras discussões sobre a arte como manifestação cultural. Como se sabe, o termo arte é oriundo do latim ars que, por sua vez, vem do grego techne. Assim, arte significava, inicialmente, um campo da atividade humana que fazia oposição ao acaso, ao natural, pois necessitava de um conjunto de regras que a orientasse. Entre os primeiros pensadores que se dedicaram a discorrer sobre a Arte estão Platão e Aristóteles. Se Platão não separava Arte de ciência e de filosofia, sendo todas entendidas como artes específicas, já Aristóteles fez uma separação que julgou necessária entre aquilo que não pode ser diferente do que é, como a ciência-filosofia, daquilo que seria possível de ser elaborado e, portanto, pode ser diferente do que é, como a arte. No campo do possível a arte foi considerada como poesis, ou fabricação, e ligada ao universo do trabalho aproximando-se do desenvolvimento técnico de habilidades. Aqui, a arte se distancia das abordagens 
transcendentais e, consequentemente, das perspectivas auráticas, entre elas aquelas que acreditam no dom ou talento natural. Sob este prisma, as atividades artísticas performativas dependeriam de uma espécie de treinamento específico para o ofício que deveria compreender o desenvolvimento da presença cênica como elemento fundamental da prática.

Subsequentemente, diversas subdivisões foram feitas por outros pensadores, mas o que importa destacar é apenas a separação entre artes liberais e artes servis ou mecânicas, feita por Varrão no século II d.C. e que ecoou por muito tempo, até o século XV. As primeiras, as artes liberais, eram dignas dos homens livres englobando a lógica, a retórica, a aritmética, astronomia, a música, entre outras. As segundas compunham um conjunto de saberes técnicos para resolver dificuldades corporais e eram voltadas para o trabalhador manual, reforçando uma estrutura baseada na estratificação social, bem como alicerçando o desprezo pelo trabalhador manual. Entre elas estava a medicina, a arquitetura, a agricultura, a pintura, a escultura. Assim, as artes liberais eram superiores às servis, porque a alma era considerada livre $\mathrm{e}$ o corpo uma prisão. Mas, com a Renascença, veio o advento do humanismo perpassado pela crescente valorização do corpo e, progressivamente, o crescimento do capitalismo dignifica o trabalho enquanto fonte de riqueza. Assim, as artes mecânicas, que haviam conquistado a condição de artes liberais por terem sido consideradas fruto do conhecimento humano, passaram a dividir-se em artes úteis - medicina, agricultura e outras e artes sem fim utilitário ou funcional, mas com fim voltado para produção do belo. Neste extenso período histórico as artes vão acomodando-se, mais ou menos, como se entende até os dias atuais e delineando sua especificidade. No ocidente, as artes da cena foram se enquadrando em linguagens delimitadas e nomeadas como teatro, dança, ópera, entre outras.

Segundo Chauí (1995, p. 318-319), por volta do século XVIII, em consequência da busca pelo belo, a obra de arte se tornou inseparável do público e de seu juízo de gosto, algo amplamente estudado por Kant, constituindo a 
base da estética, futuro ramo da investigação filosófica que tem por objeto as artes. Com o objetivo focado na busca pelo belo surgiram as belas artes e o entendimento do artista como indivíduo genial, espontâneo, sensível e dotado de inspiração criativa, recuperando temporariamente a antiga qualidade aurática, porém, agora ela dividia espaço com a razão, refletindo a crise romântica. O persistente retorno da qualidade aurática da arte transita, ainda, pela progressiva passagem do teocentrismo para o antropocentrismo, calcando a crença mais no talento natural do que no dom divino. Ser um performer da cena, nesta época, dependia do talento vindo de nascença, que desembocava nos monstros sagrados. Os artistas considerados talentosos se destacavam sobre os outros. Neste contexto, o talento poderia ser entendido como sinônimo de presença cênica, termo que vem a ser cunhado séculos depois.

Durante os séculos XIX e XX estabeleceram-se profundas transformações que modificaram os conceitos de técnica e de arte afetando as relações entre ambos. Um segmento da técnica desdobrou-se e passou a ser uma forma de conhecimento e a denominar-se tecnologia. As artes deixaram de ser produto de um gênio e de ter uma aura misteriosa, passando a ser o produto da expressão criadora através da transfiguração do real em uma obra artística. Enquanto trabalho de expressão reaproximaramse das técnicas e da ciência, definindo-se pelas linguagens próprias e reafirmando a busca pela autonomia. Desta forma, a ciência e a tecnologia passam a determinar as habilidades humanas, inclusive o fazer artístico. A partir deste paradigma começam a aparecer, ainda que timidamente, esforços no sentido de desenvolver técnicas e procedimentos metodológicos para o trabalho laboratorial dos performers.

Não se trata de afirmar que antes disso nenhuma atitude havia sido tomada no sentido de desenvolver formas de trabalho para os performers da cena. Existem poucos e esparsos registros que podem ser considerados seus embriões, pois, algumas tentativas isoladas de sistematização do trabalho do ator tiveram certa repercussão como, por exemplo, alguns manuscritos de 
Goethe. Segundo Berthold (2000, p. 418), eram notas escritas em pedaços de papel, avulsos, sobre seu trabalho diário, compondo noventa e um parágrafos sobre técnica da fala, recitação, declamação, posturas do corpo, atuação conjunta e agrupamentos em quadros estilizados. A autora acrescenta que "Gramáticas da arte de atuação existiram em todas as épocas em que a reflexão crítica foi mais forte que a vitalidade mímica e o intelecto ponderador mais pesado do que a emoção espontânea" (Berthold, 2000, p. 418).

Outro fator a ser considerado é que, com o surgimento do diretor criador, bem como com as novas possibilidades geradas pelo advento da eletricidade, iniciou-se uma preocupação mais recorrente com a formação do performer e com o registro das sistematizações. Para dar conta das exigências da mente inventiva dos diretores criadores os agentes das artes da cena passam a buscar cada vez mais o aprimoramento de seu trabalho. Assim, diversos diretores dedicaram-se a desenvolver processos sistemáticos no intuito de obter qualidade técnico-expressiva em suas encenações.

No século XX, a ideia de juízo de gosto foi completamente descartada enquanto critério de apreciação e avaliação, pois a intenção de produzir o belo é abandonada em busca da expressão, da interpretação e crítica social, da criação de procedimentos, enfim, de questões que reaproximam a arte da antiga ideia aristotélica de poética, de arte como trabalho, como produção de um conhecimento específico a ser transmitido e, finalmente, distanciando-se quase que completamente de sua qualidade aurática, que insiste em sobreviver em diversos segmentos de acordo com os diferentes contextos socioculturais. A estética volta suas investigações para as relações entre arte e natureza, arte e humano, buscando entender as finalidades e funções da arte apoiada em duas concepções principais, a expressiva e a pedagógica. Este entendimento encontra eco nos atuais cursos de ensino superior de artes, nas opções frequentemente oferecidas de bacharelado e licenciatura. Como se pode observar, a transmissão e produção do saber artístico ocupa cada vez mais seu espaço em 
ambientes formais de ensino buscando desvendar as inquietações de sua área de conhecimento. Entre as inquietações mais presentes nas artes performativas está a discussão sobre a presença cênica.

O mundo contemporâneo adentra o século XXI sofrendo profundas e rápidas transformações em meio às novas tecnologias que rompem as antigas fronteiras, sejam elas políticas, geográficas, culturais, econômicas, mediáticas, de linguagem, entre outras. De acordo com o Schechner (2002), as fronteiras diluíram-se, substituíramse, tornando-se porosas e rarefeitas, abalando as ideias de referenciais e paradigmas fixos. $\mathrm{O}$ processo de desfronteirização - que aparece claramente nas artes cênicas, com o entrecruzar de linguagens evocando a pluralidade e as simultaneidades da cena - propõe sistemas dinâmicos que ampliam significativamente as possibilidades perceptivas e participativas dos envolvidos, dilatando as possibilidades performativas.

A arte, portanto, vislumbrada enquanto trabalho profissional - produção de conhecimento que transfigura o real em busca de uma comunicação sob forma de expressão - tem dialogado com a ciência e a tecnologia, produzindo uma cultura erudita, intelectualizada, tendendo à elitização, e proporciona uma multiplicidade de conhecimentos, de informações e suas consequências no sentir, no pensar e no agir humanos. Algumas manifestações artísticas performativas, pelo contrário, assumem uma atitude transgressora explícita no que tange à elitização, mas a complexidade das suas produções não consegue desvencilhar-se desta situação paradoxal.

Sendo assim, a arte tem assumido diferentes formas nas diversas linguagens artísticas, não existe mais uma, duas ou três propostas estéticas norteadoras, mas uma multiplicidade, que se orienta para concepções diversas, plurais, inter e transdisciplinares, no trabalho dos artistas. As transformações que se remetem, inicialmente, às escolas e estilos perpassam as questões sobre a concepção da arte e sobre as relações entre matéria e forma; as técnicas e seu papel na criação; as investigações sobre a elaboração de processos criativos e às relações com o público. As artes da cena, uma vez reconhecidas, estão 
sendo desenvolvidas e testadas sobre várias propostas para o trabalho técnico dos performers, mas surgem inquietações que se encaminham para aspectos menos palpáveis como a questão da presença cênica, por exemplo.

Neste contexto, um dos pontos cruciais para esta reflexão está na inserção da produção artística performativa em um universo onde a transmissão e a produção de conhecimentos alcançou altos patamares, especialmente ao adentrar no universo acadêmico. As pesquisas realizadas, e outras em andamento, têm resultado em investigações aprofundadas sobre o saber performativo, evidenciando uma parcela significativa de pesquisadores interessados nas questões voltadas para os estudos da presença cênica. É neste universo investigativo, em que se situam as pesquisas sobre a presença cênica, que se buscará ancorar a presente reflexão, relacionando-a ao seu aspecto improvisacional.

Em meio a este complexo e até conturbado contexto foi visto que as artes da cena são pontuadas por uma infinidade de linguagens voltadas para o jogo performativo, compondo-se de espetáculos de dança e de música, de mímica, de apresentações teatrais, de happenings, de óperas, entre outras possibilidades. Especialmente, as várias manifestações híbridas, típicas da contemporaneidade, comparecem com muita frequência. Se as artes cênicas são entendidas como um tipo específico de produção cultural polida pelo intelecto e banhada de subjetividade, acredita-se que a presença cênica deve ser vislumbrada enquanto elemento a ser necessariamente estudado e desenvolvido pelo performer. Os performers destas artes transitam entre a mímeses e sua abstração ao esculpir-se em uma corporeidade poética que revela plasticamente o invisível. Para isto, ele deve ser hábil para fluir no espaço/tempo da performance e estar à vontade para estabelecer uma comunicação imediata e não objetiva com o público. Sendo assim, pretendeu-se focar as especificidades que pontuam as características da performatividade nas artes cênicas para fazer o recorte destinado ao estudo da presença em seu aspecto improvisacional.

Gisela Reis Biancalana, A Presença Performativa nas Artes da Cena e a Improvisação

R.bras.est.pres., Porto Alegre, v.1, n.1, p. 121-148, jan./jun., 2011.

Disponível em http://www.seer.ufrgs.br/presenca 
As artes da cena atravessaram diferentes épocas e culturas, refletindo as maneiras de ser e de pensar de seu tempo e local, passando por escolas e estéticas diversas, construindo e abolindo edifícios teatrais das mais distintas formas, até fragmentar-se assumindo formas multifacetadas, perpassadas por mediações tecnológicas, ou mesmo negar a si mesma. Assim, as artes cênicas, ao abrirem-se em um leque de linguagens, desembocam em discussões sobre a performatividade, levantadas por diversos pesquisadores. Segundo Pavis $(1999$, p. 25), elas justificam-se por caminhos diversos como a inclinação para o jogo, o desejo mimético, o ritual, o prazer de contar histórias ou de metamorfosear-se. O conceito de personagem teatral também sofreu variações de acordo com os contextos históricos em que se inseria e, atualmente, foi colocado em xeque, questionado sobre sua autenticidade, necessidade, importância, coerência, acionando a liberdade de buscar o heterônimo muito comum na dança.

Ao debruçar-se sobre as artes da cena, inevitavelmente se depara com o trabalho dos performers: atores, bailarinos e todos aqueles que são indispensáveis ao acontecimento performativo. Antes de tudo, as artes da cena, segundo Pavis (1999, p. 27) são performativas, de acordo com o conceito explorado anteriormente, ou seja, são definidas pela apresentação direta do performer sem intermediação, "[...] não adiada ou apreendida por um meio de comunicação, do produto artístico". Independente da linguagem ou da concepção artística importa reafirmar sua principal e intrínseca característica de comunicação imediata. Esta característica é uma das principais determinantes na consideração da necessidade de um trabalho corporal específico para cena, comportando a abordagem do seu aspecto improvisacional atrelado ao estudo/desenvolvimento da presença cênica.

Mas, o que há de comum em tanta diversidade nas artes cênicas? Um ponto de união entre diferentes épocas, locais e culturas é o performer. De acordo com Pavis (1999, p. 25) o teatro hoje é o espaço do "voyeurismo institucionalizado". O performer é a figura que

Gisela Reis Biancalana, A Presença Performativa nas Artes da Cena e a Improvisação

R.bras.est.pres., Porto Alegre, v.1, n.1, p. 121-148, jan./jun., 2011.

Disponível em http://www.seer.ufrgs.br/presenca 
permanece inabalável, em seu posto central, para onde os olhos convergem fascinados. O seu corpo presencial é a matéria concreta e ainda primitiva que exerce atração dos olhares do público. Em meio à emergência das novas tecnologias e da complexa sociedade contemporânea permanece este ser que, em sua simplicidade física, tem tanto a oferecer. Ao atravessar e responder às diferentes concepções e linguagens é a atividade performativa que celebra o acontecimento cênico. Meyerhold (1989), em seus enunciados sobre a biomecânica, já chamava a atenção sobre o fato de que a arte do ator é a organização de sua matéria.

18. Tout art est l'organisation d'un matériau. Pour organiser son matériau, l'acteur doit avoir une resérve colossale de moyens techniques. La difficulté et la spécificité de l'art de l'acteur résident em ce que l'acteur est à la fois matériau et organisateur. L'art de l'acteur est chose subtile. L'acteur est à chaque instant compositeur (Meyerhold, 1989, p. 216-217).

O performer, sendo o elemento fundamental das artes da cena, transfigura-se em corpo-arte, agente de si na construção, organização e elaboração de sua corporeidade poética. Portanto, a arte do performer, como em qualquer profissão, requer a aquisição de competências. Entre estas diversas competências residem as questões técnico-expressivas adquiridas em treinamentos laboratoriais e as questões voltadas para a presença pautada no desenvolvimento de uma corporeidade (corpo/voz) poética, voltada para as necessidades da cena como, por exemplo, a habilidade para o improviso, entendida aqui como elemento intrínseco à arte performativa. Uma performance artística, por mais formalizada que seja, comporta ao menos um certo grau de improvisação, simplesmente por ser efêmera.

Para situar a improvisação nas atividades performativas basta lançar um olhar para as primeiras manifestações das artes da cena das quais se tem conhecimento. Nota-se que, de acordo com a bibliografia especializada, elas possuíam um cunho religioso que

Gisela Reis Biancalana, A Presença Performativa nas Artes da Cena e a Improvisação

R.bras.est.pres., Porto Alegre, v.1, n.1, p. 121-148, jan./jun., 2011.

Disponível em http://www.seer.ufrgs.br/presenca 
partia da encenação da vida sobrenatural e foram, pouco a pouco, surgindo representações sobre a realidade humana, tornando-se cada vez mais complexas de acordo com épocas, locais, culturas, estéticas, propostas filosóficas ou sociais, enfim, desembocam atualmente num amplo universo de possibilidades. Destarte, de certa forma, tudo que se tornou instituído, reconhecido, às vezes oficializado, teve uma origem, uma criação, uma primeira vez. Este momento inicial não deixa de ser uma espécie de improvisação, um ensaio, uma experimentação, uma tentativa de acerto. À medida que este processo vai se tornando eficiente e necessário, vai se reafirmando através da repetição e promovendo uma espécie de identificação que assume um status cada vez mais definido, solidificado e que assume seu lugar no tempo e no espaço. Desta forma, a história das artes cênicas e da improvisação se entrecruza de diversas maneiras, sendo esta supracitada apenas uma delas. Desenvolver uma longa reflexão sobre suas origens seria uma tarefa desnecessária e deveras repetitiva, visto as inúmeras publicações que se debruçaram sobre ela. Portanto, buscar-se-á, apenas traçar as aproximações entre as atividades performativas nas artes cênicas e os processos improvisacionais que a perpassam.

Em função de sua própria natureza, é fácil verificar, brevemente, como se transmuta e como se faz presente, a improvisação nas artes cênicas em suas mais diversas formas. Há momentos em que a improvisação funcionou apenas como alavanca para impulsionar $\mathrm{o}$ surgimento de outras formas que se tornaram definitivas até hoje. No extremo oposto, há períodos onde sua manifestação ganhou tamanha autonomia ao funcionar como meio de expressão e mostrou-se tão significativa que chegou a influenciar diversas formas de manifestações contemporâneas. A improvisação enquanto meio para estimular processos criativos também se faz presente de formas diferenciadas.

$\mathrm{Na}$ cultura helênica, por exemplo, quando as artes da cena atingiram altos níveis de formalização, passou-se a abominar a improvisação considerando-a apenas uma raiz do teatro formal, uma espécie de pré-teatro. $\mathrm{Na}$

Gisela Reis Biancalana, A Presença Performativa nas Artes da Cena e a Improvisação

R.bras.est.pres., Porto Alegre, v.1, n.1, p. 121-148, jan./jun., 2011.

Disponível em http://www.seer.ufrgs.br/presenca 
tragédia, a improvisação foi minimizada, sobrevivendo pelo seu caráter efêmero e sustentando fragilmente suas relações com a presença cênica. Por outro lado, a comédia amplia suas relações com a improvisação através da imitação e do gosto pela caricatura. Os espetáculos, cômico-populares, utilizavam bastante a improvisação. Suas principais formas, o fescênio e a saturae, eram improvisações livres de canto e dança apresentadas em festivais. As atelanas, "[...] pequenas farsas de caráter bufão" (Pavis, 1999, p. 28), das quais se tem notícia desde o século II a.C., foram consideradas o embrião da Commedia Dell'Arte. As improvisações nas artes da cena sempre existiram e nutrem-se, especialmente, entre as camadas populares, carecendo de registro uma vez que eram marginalizadas por provocarem a excitação do público.

$\mathrm{Na}$ Commedia Dell'Arte, tipo de manifestação teatral surgida no Renascimento, a improvisação tinha um papel relevante. Apesar das controvérsias a respeito do papel da improvisação neste estilo teatral, ela foi um elemento de grande significação devido ao jogo que estabelecia com o público nas praças das cidades, conferindo-lhe seu caráter popular. A Commedia Dell'Arte caracteriza-se pela fixação de personagens tipo, pelo uso de máscaras e, particularmente, por um esquema de improvisação sobre uma estrutura estabelecida pelos atores/autores, os canevas ou conovaccio. A atuação dos atores era excelente devido a grande preparação técnica, vocal, coreográfica, acrobática, cultural. Os textos e os personagens não eram improvisados, os atores levavam grande parte da vida na construção de seus personagens, e exercitavam a arte de improvisar dentro de seus roteiros bem fixados. No século XVIII, a Commedia perdeu sua força por renegar aquilo que a enaltecia: as aberturas para improvisação. Tornou-se um teatro reproduzido por memórias inseguras, devido à escassez de registro, pois a cena era registrada mais na memória dos atores do que no papel. Atualmente, tem sido novamente recuperada, valorizada e estudada.

Além da Commedia, a improvisação continuou viva na história das artes cênicas, em incontáveis formas

Gisela Reis Biancalana, A Presença Performativa nas Artes da Cena e a Improvisação

R.bras.est.pres., Porto Alegre, v.1, n.1, p. 121-148, jan./jun., 2011.

Disponível em http://www.seer.ufrgs.br/presenca 
espetaculares tomando diversos rumos e influenciando muitas gerações até a atualidade. Entre tudo que foi usado como improvisação, seja na formação dos atores, seja nos processos criativos, seja como um elemento da performance, é importante destacar que as fortes transformações ocorridas na primeira metade do século XX também alimentaram deveras o futuro das artes da cena, da improvisação e das inquietações sobre o possível desenvolvimento da presença. As formas parateatrais do pós-guerra como o dadaísmo, bem como manifestações apoiadas na contracultura como a live art, por exemplo, foram formas de contestação e contribuíram significativamente, uma vez que absorveram a improvisação como elemento integrante das apresentações desencadeando uma infinidade de possibilidades. Nos EUA, por volta dos anos 1960, o rompimento da quarta parede gerou o teatro participação. Os grupos teatrais que desenvolvem trabalhos nesta linha convertem cada representação em acontecimentos coletivos e ultrapassam os limites do edifício/palco para as ruas. O clima de contestação política-social deste tipo de manifestação perdeu sua força atualmente, mas a ideia de participação coletiva permaneceu. As formas parateatrais, como os happenings e os events, só acontecem a partir do momento que começa a relação entre proponentes e público, eles se fundem e o resultado emerge desta relação que, se inexistente, impossibilita o acontecimento que só acontece via improvisação. As performances, enquanto linguagem, são oriundas deste ambiente, sendo responsáveis por grandes transformações ocorridas em diversas manifestações artísticas dos fins do século XX, principalmente no que se refere à incorporação da improvisação.

Em meio ao clima de inovações a improvisação amplia suas relações com as artes da cena. $\mathrm{Na}$ contemporaneidade, a aceleração do tempo exige ação e reação instantâneas por parte do performer. As aproximações e a diversidade de relações que estabelece com o público requer rapidez nas soluções que se apresentam momentaneamente. $\mathrm{O}$ uso do fragmento impõe atenção diante de cada situação que se precipita. A

Gisela Reis Biancalana, A Presença Performativa nas Artes da Cena e a Improvisação

R.bras.est.pres., Porto Alegre, v.1, n.1, p. 121-148, jan./jun., 2011.

Disponível em http://www.seer.ufrgs.br/presenca 
hibridização de linguagens também aspira uma abertura do corpo-arte para ser permeado pelo desconhecido que o convida a tornar-se conhecido. A flexibilidade, portanto, parece ser uma característica fundamental para qualquer performer contemporâneo à medida que se multiplicam em simultaneidades os tempos e os espaços, ampliam-se as formas de atuação que, por sua vez, podem transformar-se e surpreender a cada instante.

Apenas no intuito de situar o surgimento do conceito de improvisação teatral no Brasil, buscou-se enfocar, brevemente, uma de suas grandes pesquisadoras, Viola Spolin (1992). Seu livro Improvisação Para o Teatro foi traduzido para o português por sua divulgadora Ingrid Koudela, em 1979, desde então suas propostas exerceram profunda influência nos meios teatrais brasileiros. Nessa época, imperava o ideal pedagógico escolanovista de John Dewey no qual o ensino se dava através da ação reconstruindo a experiência concreta, ativa e produtiva dos educandos. Pragmática, a escola nova pregava que a experiência concreta da vida se apresenta diante da solução de problemas (Gadotti, 1993, p. 143). De acordo com Spolin, a contemporaneidade é regida por juízos de valores padronizados como o sim e o não, o certo e o errado, o bom e o mau, entre outros, que regulam as atividades humanas, tolhendo seu poder de escolha e decisão. Desta forma, as propostas de educação teatral de Spolin têm a influência de concepções de ensino escolanovistas preocupadas com o processo em detrimento do resultado. Ao partir do pressuposto de que todas as pessoas são capazes de jogar e improvisar através da experiência, Spolin afirma que "Se o ambiente permitir, pode-se aprender qualquer coisa, e se o indivíduo permitir, o ambiente lhe ensinará tudo que ele tem para ensinar" (1992, p. 3). Acredita-se que a possibilidade de que uma pessoa, sendo considerada talentosa, talvez tenha apenas capacidade e disponibilidade para experienciar. A partir das colocações de Spolin, a habilidade para improvisação pode não ser um dom, nem um talento, e poderia ser desenvolvida como qualquer técnica. Este pressuposto vai de encontro à crença no talento que chega a poucos escolhidos. $\mathrm{O}$ 
mundo conhecido é visível, palpável, então, o papel do performer é reelaborá-lo, enquanto corpo-arte, para estabelecer a comunicação almejada.

O mundo fornece o material para o teatro, e o crescimento artístico desenvolve-se par e passo com o nosso reconhecimento e percepção do mundo e de nós mesmos dentro dele $[. .$.$] No teatro [...] o ator aprende que a realidade$ do palco deve ter espaço, textura, profundidade $\mathrm{e}$ substância, isto é, realidade física (Spolin, 1992, p. 13-15).

O teatro, diante do complexo e multifacetado mundo contemporâneo, continua a concentrar certa atração pelos aspectos primitivos de que necessita para sustentar sua permanência. O corpo em cena é matéria primitiva frente à tecnologia, à intelectualidade, à virtualidade. No Brasil, seguindo este caminho, José Celso Martinez Corrêa e Augusto Boal desenvolveram suas pesquisas. Para o primeiro, a improvisação deveria levar a liberação individual e a expressão do eu, para o segundo deveria levar a liberação coletiva com enfoque político social no seu Teatro do Oprimido. Assim, com a intensificação das experimentações, baseadas na improvisação, amplia-se o interesse pelos seus possíveis processos no momento em que a prática extravasa para grandes polêmicas. Ao trabalhar nos limites interdisciplinares e fundir conhecimentos de áreas diversas se alargam e se enriquecem as possibilidades de improvisação nas artes performativas.

Mas, afinal, qual o papel da improvisação para os artistas em contextos laboratoriais e performativos? A improvisação, seja qual for o nível utilizado em cena ou forma de aplicação nas artes, possui objetivos extremamente fecundos, como meio para experimentação, focados na criação cênica; como desenvolvimento do domínio da cena ajudando o ator a manter seu jogo cênico vivo e sua performance não cristalizada; como linguagem voltada para a capacidade de atuar ao improviso; como facilitadora da capacidade de atuar diante de circunstâncias imprevistas, preparando os artistas para agir e reagir instantaneamente. Especialmente, os processos artísticos improvisacionais

Gisela Reis Biancalana, A Presença Performativa nas Artes da Cena e a Improvisação

R.bras.est.pres., Porto Alegre, v.1, n.1, p. 121-148, jan./jun., 2011.

Disponível em http://www.seer.ufrgs.br/presenca 
alavancam a presença ao ativar a atenção que objetiva o foco. Assim, a improvisação é um elemento inerente às artes cênicas, pois " [...] a vida da representação teatral é uma realização irreversível no sentido de 'ser em determinado momento'. Este fenômeno da vida e do teatro - mesmo quando esta vida e este teatro são programados - não prescinde do imprevisível" (Chacra, 1991, p. 8). Particularmente, a improvisação, quando incorporada à linguagem, pode constituir-se numa ferramenta eficaz ao desenvolver a competência voltada para o fenômeno performativo. Portanto, fez-se necessário observar, primeiro, como ela vem sendo entendida a fim de desencadear uma reflexão sobre as formas de utilização, na contemporaneidade, que possam contribuir com os estudos da presença.

No que se refere aos fundamentos da improvisação, Chacra (1991, p. 39-41) observa, basicamente, dois polos diferentes na abordagem do termo, um apoia-se no termo Teatro Improvisado e o outro no termo Improvisação Teatral. Segundo a autora, ao utilizar o nome Teatro Improvisado, corre-se o risco de entender que uma obra teatral foi realizada improvisadamente pelos agentes da cena quando se quer dizer outra coisa. Se a improvisação é um elemento constituinte do teatro, a expressão Improvisação Teatral se tornaria mais ampla e mais abrangente, podendo fazer parte do teatro desde sua versão intencionalmente improvisada até as versões altamente formalizadas. Destarte, teatral indicaria uma qualidade da improvisação realizada em contextos dramáticos. Ao assumir o termo improvisação enquanto qualidade das práticas teatrais ainda resta explorar os seus diversos níveis existentes, bem como suas diversas maneiras de aplicação em contextos teatrais, seja na preparação dos atores, em laboratórios de criação ou destinadas a interação durante a cena, entre os atores e/ou com o público.

As artes da cena sempre comportam algum grau de improvisação devido à efemeridade inerente a ela. Sendo assim, a improvisação nas artes cênicas se assenta sobre dois polos de uma mesma linha, de um lado está o seu nível máximo e, do outro, o seu nível mínimo. Neste 
meio se encontrariam níveis de improvisação que denotariam um caráter mais ou menos improvisado na manifestação teatral, de acordo com a concepção cênica proposta. Em qualquer dos níveis citados o fenômeno teatral busca parecer instantâneo, o público precisa acreditar que aquilo que vê está acontecendo pela primeira vez diante dos seus olhos, mesmo que isso seja uma convenção fictícia. Para Chacra é "[...] o fenômeno teatral que traz como elemento fundamental à improvisação, responsável pela vitalidade da arte no palco, [...], provocando nos que fazem e nos que vêm, reações e sensações inesperadas, resultando num produto final imprevisto" (Chacra, 1991, p. 20). Observa-se, por esta citação, que a autora acredita na improvisação como elemento fundamental do fenômeno teatral, atribuindo a ela grande responsabilidade.

A improvisação que acontece como proposta cênica, ou seja, a criação, é gerada durante a performance pública e tem sido uma forma muito experimentada. Existem aqui, também, inúmeras maneiras de exploração desta proposta nas artes cênicas. Pode-se encontrar pontos fixos, por exemplo, a partir dos quais se improvisa, como temas, partituras de movimento, sons, roteiros, entre outros. A improvisação também pode acontecer devido à interferência concreta do público quando este é convidado a interagir com a cena, tal como acontece desde os happenings e outras formas das Vanguardas. Chacra (1991) faz referência ao talento para improvisação, postura que diverge das afirmações de Spolin sobre o mesmo assunto.

A utilização de algum tipo de esquema como ponto de partida para realização cênica, em substituição a obra dramatúrgica de cunho literário, sem dúvida abre caminho para o florescimento da escritura de uma peça atuada, isto é, improvisada. Quando a responsabilidade maior de tal tarefa fica circunscrita à esfera atoral, os improvisos são realizados por pessoas capacitadas, quando não, por artistas com um talento excepcional de improvisação, que se inspiram nos pretextos do momento, do meio e das reações do público, fazendo do espetáculo algo extremamente vivo e contagiante, sem contudo deixarem de obedecer às planificações mínimas (ou máximas), que não só constituem

Gisela Reis Biancalana, A Presença Performativa nas Artes da Cena e a Improvisação

R.bras.est.pres., Porto Alegre, v.1, n.1, p. 121-148, jan./jun., 2011.

Disponível em http://www.seer.ufrgs.br/presenca 
a espinha dorsal da representação, como ladeiam embaraços eventuais (Chacra, 1991, p. 63).

O elemento relevante desta reflexão remete-se ao performer no palco, as ocorrências cênicas e sua intrínseca natureza efêmera. Devido a essa natureza efêmera das artes da cena, o performer está sempre improvisando, em cada instauração do fenômeno cênico, como foi visto, em maior ou menor nível, dependendo da proposta para concepção artística. Os processos improvisacionais flutuam desde o espetáculo mais formalizado ao que cria durante a performance, passando pelos que utilizam a improvisação como procedimento metodológico da criação ou mesmo quando se deixa espaço para o improviso nos espetáculos. Icle (2002) ao colocar o teatro como espaço de construção do conhecimento, também evoca a extrema importância da abordagem de processos improvisacionais, que permeiam o trabalho do ator.

Historicamente, o teatro convencional do ocidente, por exemplo, tinha suas raízes profundamente enraizadas na literatura dramática e na ação previamente definida. $\mathrm{O}$ ator construía sua atuação a partir da interpretação de textos e personagens voltadas para a representação. Ação, aqui, pretende significar uma atitude psicofísica sustentada pelo performer inserida em uma situação cênica e que corresponde ao seu objetivo imediato com precisão e clareza de expressão e/ou comunicação. Esta vertente hermenêutica já foi bastante questionada e as inquietações dela provenientes derramaram-se em novas perspectivas apoiadas na introdução das formas não interpretativas.

Nestas manifestações cênicas elaboradas e fixadas por marcações textuais e partituras de ação definidas, o simples fato da plateia não saber o quê ou como as situações vão acontecer no palco gera, no performer, um estímulo e disposição para surpreendê-la através de sua representação, dando sentido a sua arte. A improvisação também surge deste contexto de querer convencer $o$ público, onde o pré-estabelecido confronta-se com o novo. O público não é receptor passivo, ele provoca um 
efeito na performance dos atores com resultado direto em seu desempenho, no momento da captação se estabelece uma troca evidente entre ambos. Entender a plateia como elemento passivo, quando ela não se movimenta ou não interfere na ação concreta que vai acontecer, há muito tempo tem sido rejeitada. A plateia é ativa em sua própria forma de assimilar o que acontece no palco. O público também é ativo quando sua forma de recepção influencia o trabalho do performer, se não no que ele faz, ou seja, na ação realizada, mas através dos estímulos que envia a ele influenciando o seu modo de fazer, ou seja, como ele faz. Neste modo de fazer também residem as discussões sobre a presença, pois, se o fenômeno cênico acontece a partir da relação de troca entre performers e espectador, quanto mais profunda for a troca, quanto mais qualidade se estabelecer nas relações, há uma implicação direta na atuação performativa, como uma espécie de estímulo. Assim, acredita-se que a inter-relação também é um elemento capaz de conferir ao espectador uma importância fundamental na presença cênica dos performers.

Desse modo, a improvisação no teatro tradicional do ocidente se apresenta com pouca frequência $\mathrm{e}$ intensidade, pois o trabalho é extremamente elaborado. Como sua aparição ocorre no interior da estrutura espetacular funde-se com ela podendo ser imperceptível até para o próprio performer. Mas, as circunstâncias imprevistas, que exigem o improviso, podem alterar a presença performativa e estabelecer uma situação extraordinária. $\mathrm{O}$ performer precisa de certa flexibilidade cênica que lhe permita agir concretamente diante do público em uma situação, fixada ou não, perante um imprevisto. O performer é o responsável direto pela concretização cênica no contato com o espectador em um determinado momento, implicando nos imprevistos com os quais ele precisa saber lidar, pois ao surgir qualquer situação inesperada como esquecer o que fazer ou falar, cair o cenário, parar energia elétrica, lidar com algum erro cometido pelos colegas ou pela contra-regragem, cabe a ele recuperar a linha de ação obstruída e, se for possível, sem que o público perceba. É neste momento 
que se torna necessário o uso de um tipo específico de improvisação, ação imediata, às vezes reflexa, diante do inesperado.

No outro extremo estão as performances com altos níveis de improvisação e que propõe a participação concreta do público. Estas propostas são normalmente apresentadas por performers criadores que são muito sensíveis ao público e estabelecem, a partir de sua atuação, um relacionamento livre com ele que, por sua vez, se sente mais à vontade para reagir. O performer não sabe de antemão como vai reagir diante das situações que se apresentam a ele. O performer vai mobilizar a aproximação do público em direção à improvisação coletiva e retirá-lo da apreciação estética intelectual. Para assimilar esta forma de improviso, que joga mais intensamente com reações inesperadas, é necessário que o performer tenha muita predisposição, muita atenção e seja sensível aos outros participantes e/ou ao público. Quando o trabalho baseia-se numa proposta de criação em performance, a atenção e a sensibilidade às reações instantâneas se multiplicam pela falta de apoios advindos das marcações de cena, seja do texto definido, de partituras de ação, entre outras, que fornecem segurança ao ator. Mesmo que a criação parta de um ponto de apoio, o desenrolar da cena depende de atitudes tomadas no momento. Este tipo de atuação requer dedicação extrema voltada para o jogo e suas peculiaridades como prontidão, disponibilidade, atenção, além de que o exercício e a experiência, neste tipo de performance, contribuem muito para o desenvolvimento da habilidade para atuar ao improviso. As artes da cena, que implicam necessariamente em participação do público, dependendo dele para acontecer, demandam ainda mais atenção, uma vez que o objetivo do performer é sensibilizar o espectador em direção a uma comunicação e/ou expressão coletiva. A determinação do performer em mobilizar o público na direção da participação coletiva requer presença para que ele possa responder, com responsabilidade e comprometimento, às demandas destas propostas.

Vista como procedimento metodológico de criação

Gisela Reis Biancalana, A Presença Performativa nas Artes da Cena e a Improvisação R.bras.est.pres., Porto Alegre, v.1, n.1, p. 121-148, jan./jun., 2011. 
para a cena, a improvisação tem sido usada com muita frequência e de incontáveis formas como meio para alcançar os objetivos cênicos buscados pelos artistas, diretores ou atores. A improvisação como meio para estimular a criação e, consequentemente, a composição de cenas é um instrumento fomentador valioso, desde que aplicado com coerência. Saber escolher os caminhos que possam impulsionar a criação de acordo com a proposta estética, a concepção cênica e a linguagem almejada é tarefa árdua. As variadas maneiras de utilizar a improvisação como meio de criação são baseadas em percursos também variados. Elas podem diferir simplesmente na temática ou fonte temática, podem diferir no grau de liberdade dos performers, podem diferir na abordagem dos exercícios e treinamentos, enfim, o repertório de possibilidades é interminável, visto que se cria não apenas a obra, mas também as formas de criação com coerência. Este repertório infinito de exercícios e jogos pode não ajudar em nada se não forem administrados com coerência, pois os processos criativos não se baseiam apenas na escolha de propostas préestabelecidas e jogos retirados de um manual para atores, mas de sensibilidade artística e conhecimento profundo do ofício. A riqueza da improvisação, nestes contextos metodológicos, está na possibilidade dos performers trabalharem com material criativo buscado em si, no repertório acumulado em sua memória corporal e capaz de instaurar o novo via procedimentos improvisacionais. As buscas recorridas a si, no contato com a produção criativa, proporcionam uma experiência sincera e este acreditar em si pode impulsionar o desenvolvimento da presença.

A reflexão a respeito da improvisação em atividades performativas, bem como sua relação intrínseca com os estudos da presença, acompanham as reflexões sobre as abordagens de grandes mestres das artes da cena. As suas investidas laboratoriais caminham em busca da presença, que ecoa de discussões e proposições anteriores, batizadas de verdade cênica, de segunda natureza, nas palavras de Stanislawski (1985); do bios cênico, da pré-expressividade, do corpo 
extracotidiano, nas palavras de Barba (1994); do corpo subjétil, nos textos de Ferracini (2003); da restauração do comportamento, segundo Schechner (2003); e mesmo no corpo santo de Grotowski (1992), apenas para citar alguns dos desdobramentos mais conhecidos.

Assim, acredita-se que as performances competentes $^{1}$ e seu tom mágico, oriundo da polêmica que gira em torno da existência ou não de um talento, também são atraentes pela imprevisibilidade da atuação instantânea com a qual vem a expectativa provocada pelo risco, excitante para todos os presentes. A habilidade para o improviso gera tensão e, por este motivo, um corpo em performance precisa saber lidar com o desafio do inusitado.

Um fator interessante a ser considerado é que os performers comumente têm um repertório com inúmeras possibilidades para lidar com a efemeridade, pois, a improvisação praticada nos processos performativos em arte é pautada por regras pré-estabelecidas. Performances acontecem a partir de parâmetros e de regras sobre as quais se alicerçam os referenciais determinados pela linguagem artística que representam. $O$ jogo que se estabelece entre performers e público traz a segurança oferecida pelos elementos regrais fixados, mas o imprevisto excita. Assim, mesmo com regras estabelecidas, fixadas, estas manifestações elaboram-se no momento e estão intimamente ligadas à presença cênica. Pontuar os níveis de aplicação da improvisação em uma linguagem cênica específica é tarefa simples, pois elas são orientadas pelas regras e inseridas em circunstâncias definidas.

Nos contextos apontados até agora, as aberturas para improvisação fornecem possibilidades significativas para o desenvolvimento e manutenção da presença, uma vez que o fato de estar jogando no improviso pressupõe um estado de alerta que anima os performers, possibilitando a constante renovação criativa. É no exercício do improviso que os performers desenvolvem uma disponibilidade que favorece a renovação e se presentificam. É fundamental considerar, ainda, que os fatores circunstanciais e os fatores individuais do

Gisela Reis Biancalana, A Presença Performativa nas Artes da Cena e a Improvisação

R.bras.est.pres., Porto Alegre, v.1, n.1, p. 121-148, jan./jun., 2011.

Disponível em http://www.seer.ufrgs.br/presenca 
momento, todos somados à experiência adquirida ao longo da vida, interferem na qualidade da presença de qualquer performer. Os fatores circunstanciais são afetados pelo local, a época, a cultura, os imprevistos, as relações sociais, os contatos estabelecidos durante a vida e as oportunidades aproveitadas. Os fatores individuais comportam o estado de saúde ou emocional do performer, a disciplina, a determinação e, especialmente, a sensibilidade. No entanto, fica claro que a habilidade para atuar ao improviso, seja em qualquer nível ou forma de aplicação, sustentando a presença cênica, é um elemento claramente percebido nas performances.

A habilidade para transitar simultaneamente pelos tempos real e fictício das performances artísticas, por sua vez, vem acompanhada do respeito ao tempo da natureza, ou seja, o respeito de cada um na ampliação de suas habilidades potenciais, seus limites, enfim, seu processo individual. O tempo acelerado tem sido vislumbrado, nas sociedades contemporâneas, como uma necessidade fundamental, motor do sucesso, impulsionado pelos ideais da competitividade e da produtividade. Porém, esta rapidez quase instantânea, muitas vezes, atropela o tempo da natureza, ao qual o ser humano faz parte, submetendoo, apenas, ao tempo criado artificialmente, para corresponder às exigências de um sistema, excessivamente, dinâmico. Um resultado competente faz parte de um processo integralizado onde o performer não despreza as relações humanas que se estabelecem pela via do conhecimento.

Enfim, a aquisição de competências, voltadas para os corpos-arte em atividade performativa, ainda depende daquele elemento essencial citado no início da reflexão, o desejo, talvez o mais importante, uma vez que alavanca o desenrolar de todo o processo. O desejo de fazer, elemento difícil de ser captado, é um motivador fundamental no processo de presentificação, capaz de movimentar qualquer intenção dos performers de ser um componente ativo de sua arte. Assim, parte-se do pressuposto que, supridas as exigências técnicoexpressivas para o cumprimento do ofício, o desejo de ser/mostrar-se promove a entrega generosa e dedicada, 
capaz de alavancar o desenvolvimento da competência almejada. Os processos formativos podem instrumentalizar o desejo de fazer, motor para os conhecimentos que fazem fluir qualquer atividade e impulsionam as escolhas feitas pelos performers. A escolha, motivada pelo desejo de fazer, por sua vez, deve estar acompanhada da produção dos saberes provenientes do trabalho técnico sério, comprometido e disciplinado, necessários ao cumprimento de qualquer ofício. $\mathrm{O}$ ato performativo é produção, é prática e está em processo mediante a sua concretização pública. A constante elaboração inclui a transcendência do conhecimento meramente técnico ao passar pela experiência genuína, que inclui a habilidade para atuar ao improviso, suscitando a tão almejada presença.

Assim, o desejo de fazer é fundamental nas atividades performativas e, ainda, talvez, quem sabe... o talento. Neste contexto, a reflexão buscou ressaltar que, descartando os fatores circunstanciais, há um exercício cíclico, uma espécie de ação em cadeia que envolve o processo formativo dos performers. O trabalho técnicoexpressivo, aliado ao desejo de fazer, pode promover as aberturas para o improviso, que geram a percepção proveniente do exercício de agir e reagir, instantaneamente, desembocando na criatividade artística e na presença cênica, bem como na entrega generosa às relações que se estabelecem com o público mediante a atividade performativa. 
Notas

${ }^{1}$ A competência é entendida, nesta reflexão, como a habilidade ou aptidão desenvolvida por um indivíduo ou grupo para realizar uma atividade específica de maneira adequada às suas exigências.

\section{Referências}

BARBA, Eugênio. A Canoa de Papel. São Paulo: Ed. Hucitec, 1994.

BERTHOLD, Margot. História Mundial do Teatro. São Paulo: Ed. Perspectiva, 2000.

CHACRA, Sandra. Natureza e Sentido da Improvisação Teatral. São Paulo: Ed. Perspectiva, 1991.

CHAUÍ, Marilena. Convite à Filosofia. São Paulo: Ed. Ática, 1995.

FERRACINI, Renato. O Corpo Cotidiano e o Corpo Subjétil: relações. In: $2^{\circ}$ CONGRESSO BRASILEIRO DE PESQUISA E PÓS-GRADUAÇÃO EM ARTES CÊNICAS, 2003, Florianópolis, Anais... Florianópolis: UFSC, Memória ABRACE VII IOESC, 2003. P. 85-88.

GADOTTI, Moacir. História das Ideias Pedagógicas. São Paulo: Ed. Ática, 1993.

GROTOWSKI, Jerzy. Em Busca de um Teatro Pobre. Rio de Janeiro: Civilização Brasileira, 1992.

ICLE, Gilberto. Teatro e Construção de Conhecimento. Porto Alegre/RS: Mercado Aberto, 2002.

LAPLANTINI, François. Aprender Antropologia. São Paulo: Ed. Brasiliense, 1996.

MEYERHOLD, Vsevolod. Enonces de Meyerhold sur la Biomecanique. Bouffonneries Exercice(s), Le Siecle Stanislavski, France, Revue Trimestrielle, n. 18/19, p. 215-219, 1989.

PAVIS, Patrice. Dicionário de Teatro. São Paulo: Ed. Perspectiva, 1999.

SCHECHNER, Richard. Performance Studies, an introduction. London and New York: Routledge, 2002.

SCHECHNER, Richard. O que é Performance? O Percevejo, Rio de Janeiro, UNIRIO, ano 11, n. 12, p. 25-50, 2003.

SCHElling, Vivian. A Presença do Povo na Cultura Brasileira. Tradução Federico Carotti. Campinas: Editora da UNICAMP, 1990.

SPOLIN, Viola. Improvisação para o Teatro. São Paulo: Ed. Perspectiva, 1992.

Gisela Reis Biancalana, A Presença Performativa nas Artes da Cena e a Improvisação

R.bras.est.pres., Porto Alegre, v.1, n.1, p. 121-148, jan./jun., 2011.

Disponível em http://www.seer.ufrgs.br/presenca 
STANISLAWSKI, Konstantin. Mi Vida en el Arte. Habana/Cuba: Editorial Arte y Literatura, 1985.

Gisela Reis Biancalana é bacharel e licenciada em Dança, Mestre e Doutora em Artes pela UNICAMP. É professora Adjunta do Curso de Artes Cênicas da Universidade Federal de Santa Maria (UFSM), Departamento de Artes Cênicas e atua como membro permanente do Programa de Pós-Graduação em Artes Visuais da UFSM atuando como orientadora de trabalhos voltados para Performance na linha de pesquisa Arte e Cultura. É líder de um Grupo de Estudos e Pesquisas, vinculado ao CNPq, denominado Performances: arte e cultura.

E-mail: gisbia@terra.com.br 